\title{
Derangement of Kidney Biomarkers Associated with Blood Cadmium, Lead and Chromium in Artisans and Petrol Hawkers in Jos, Nigeria
}

\author{
Bot Yakubu $\mathrm{S}^{1, *}$, Nwanjo Harrison $\mathrm{U}^{2}$, Nwosu Dennis $\mathrm{C}^{2}$, Olumide Olaniru $\mathrm{B}^{3}$, and Ifenkwe John $\mathrm{C}^{4}$ \\ ${ }^{1}$ Department of Chemical Pathology, Federal School of medical Laboratory Sciences, Jos, Nigeria \\ ${ }^{2}$ Department of Chemical Pathology, Imo State University, Owerri, Nigeria \\ ${ }^{3}$ Department of Chemical Pathology Jos Universtity Teaching Hospital, Jos, Nigeria \\ ${ }^{4}$ Federal Medical Centre, Yenagoa, Nigeria
}

*Corresponding author: Bot Yakubu S, Department of Chemical Pathology, Federal School of medical Laboratory Sciences, Jos, Nigeria, E-mail: botson2003@gmail.com

Received: 06 Feb, 2020 | Accepted: 22 Feb, 2020 | Published: 29 Feb, 2020

Citation: Bot YS, Nwanjo HU, Nwosu DC, Olumide OB, Ifenkwe JC (2020) Derangement of Kidney Biomarkers Associated with Blood Cadmium, Lead and Chromium in Artisans and Petrol Hawkers in Jos, Nigeria. Int J Nephrol Kidney Fail 6(1): dx.doi.org/10.16966/2380-5498.190

Copyright: (c) 2020 Bot YS, et al. This is an open-access article distributed under the terms of the Creative Commons Attribution License, which permits unrestricted use, distribution, and reproduction in any medium, provided the original author and source are credited.

\begin{abstract}
Chronic occupational exposure to heavy metals particularly cadmium, lead and chromium may result in renal alterations affecting both tubuli and glomeruli. We therefore examined the association of blood cadmium (B-Cd), blood lead (B-Pb), and blood chromium (B-Cr) with Estimated Glomerular Filtration Rate (eGFR) among artisans and petrol hawkers in Jos, Nigeria. Blood samples were collected from workers who were all men $(n=400)$, drawn from welders, battery repairers, petrol hawkers, tin miners and car painters with age ranging from 15-60 years with a mean value of $(35.99 \pm 10.59)$. The control group $(n=200)$ was within the range of $28-49$ years and a mean value of $(37.10 \pm 5.45)$ and the duration of exposure was limited to between 1-8 years. $10 \mathrm{~mL}$ of blood was also collected into plain tubes from each subject. Samples were allowed to stand for 15 minutes after which they were centrifuged at $3000 \mathrm{rpm}$ for 20 minutes and the serum separated with the help of a sterile Pasteur's Pippette into cryovial containers. Samples were later stored frozen at $-20^{\circ} \mathrm{C}$ pending analysis. Serum levels of heavy metals were done using AAS. Random Urine samples $(5 \mathrm{~mL})$, collected in sterile universal containers and used for the determination of micro albumin by latex agglutination methods. Serum Urea/Creatinine was done using COBAS C111 Chemistry auto analyzer. Data were analyzed using Statistical Package for Social Sciences (SPSS) version 23 and student t-test was used to compare mean values between the control and study groups. Statistically high levels of Serum $\mathrm{Cd}$, Pb and $\mathrm{Cr}$ were detected among welders, car painters and petrol hawkers in addition to the levels of Urea, Creatinine and Micro albumin, which were also statistically increased and significant $(\mathrm{P}<0.05)$ among battery repairers, petrol hawkers, car painters and welders with a corresponding eGFR $<90$ $\mathrm{mL} / \mathrm{min}$ for Car painters $77(96.3 \%)$, followed by battery repairers $60(75.0 \%)$, iron welders, $60(75.0 \%)$ and petrol hawkers $57(71.3 \%)$ respectively. We conclude that artisans and petrol hawkers in jos are prone to kidney damage due to the presence of lead, cadmium, and chromium.
\end{abstract}

Keywords: eGFR; Glomeruli; Artisans; AAS; COBAS C111; Heavy metals

\section{Introduction}

Heavy metals have been reported to be responsible for the increased in renal pathology across the globe and are currently the ninth leading cause of death in the United States [1,2], posing a serious public health menace. Aside the risk factors for Kidney disease, environmental exposures such as those caused by heavy metals eg: $\mathrm{Cd}$, and $\mathrm{Pb}$ have been reported to be nephrotoxic [3-5].

In Jos Plateau state (Nigeria) just as it is with many cities in the country, there are several Petrol hawkers, motor vehicle mechanic workshops and car painters (involved in car painting activities). Lead/ Cadmium battery repairers, welding workshops and a host of other artisans whose activities poses a serious threat to human lives owing to the fact that many of them are located in residential areas and there is no conformity to internationally accepted best practices in such work places spite of the dangers, these activities pose to human health due to heavy metal toxicity. Heavy metal toxicity is unique in view of the fact that unlike organic contaminants, they neither get degraded further nor undergo complete decomposition into other chemicals [6].

Hence, the activities of theses artisans results into the generation of gases, fumes and vapors comprising of metals and metalloids of aero dynamic diameter and can get into the system either via inhalation, ingestion or skin absorption [7-9] causing bioaccumulation in the human system, ecosystem and agricultural products which may latter be consumed by either humans or animals alike. These entire processes creates both environmental and health problems. Hence it becomes important to assess the levels of heavy metals in relation to the renal status of those directly engaged in the generation of these materials and their constituents which have been reported to be 
harmful or injurious not only to the nervous system, hepatic, or other body systems but also to the renal system.

\section{Materials and Methods}

\section{Study area}

The study was conducted at building materials, Kuru Jenta, Dilimi and Farin Gada Settlement areas of Jos North and Jos South Local Government area of Plateau State, Nigeria. Jos has a land area of about 26, 899 square Kilometers $\left(\mathrm{Km}^{2}\right)$. It is the most densely populated area in the Plateau State with about 900,000 inhabitants (NPC, 2006). It is located between $80^{\circ} 24^{\prime} \mathrm{N}$ and Longitude $80^{\circ} 32^{\prime}$ and $100^{\circ} 38^{\prime}$ East. It lies on a Plateau with an attitude that ranges from around 1,200 meters (about 4000 feet) to a peak of 1,829 meters above sea level (Figure 1).

Stratified random sampling technique was adopted and a minimum of four hundred (400) individuals were recruited. This was obtained using the Atchley's formular [10]

$$
n=\frac{z^{2} p q}{d^{2}}
$$

Where $\mathrm{n}=$ the desired sample size (target population)

\section{$\mathrm{z}=$ Standard normal deviate at the required confidence level}

$\mathrm{p}=$ proportion in the target population estimated to have the measured character

$$
\mathrm{q}=1-\mathrm{p}
$$

$\mathrm{d}=$ the level of statistical significance set

In this study, $\mathrm{z}=$ statistics was 1.96 , and the desired accuracy was at 0.05 level.

$$
n=\frac{(1.96)^{2} \times(0.5) \times(0.5)}{(0.05)^{2}}=384
$$

\section{Study population}

The study population was drawn from Building Materials, KuruJenta, Dilimi and Farin-Gada settlements of Jos South Local and Jos North Government Area of Plateau State-Nigeria. All participants were artisans involved in welding, battery repairs, selling of petrol, Tin mining and car painters. Two hundred (200) control subjects were students from University of Jos. All subjects recruited into the study were between the ages of $18-60$ years. Hence, a total of 600 subjects were recruited.

\section{Advocacy}

The Plateau State Ministry of Health granted the ethical clearance for this work. The members and leaders of the various occupations were met and informed about the study that was to be carried out in their work places. Their co-operation and support were solicited in mobilizing their subjects and informed consent was obtained from the subjects recruited into the study.

A. Inclusion criteria: Subjects who were between the ages of 18-60 that consented to the study and have spent minimum of six (6) months on the job with no prior history and treatment for hypertension and diabetes mellitus or renal disease were included.

B. Exclusion criteria: Those subjects who had prior history of tobacco smoking and treatments for hypertension and diabetes mellitus and a previous history of renal disease as well as those who refused consent were excluded from the study.

\section{Sample collection}

Blood samples were collected by venous puncture using pyrogen free sterile disposal syringes in the presence of a trained Phlebotomist according to the procedure described by Famodu AA, et al. [11] samples were analysed for heavy metals, and renal indices. Samples for evaluation of heavy metal in regards to renal parameters were collected into plain tubes. They were allowed to stand for 15 minutes after which they were centrifuged at $3000 \mathrm{rpm}$ for 20 minutes and the serum separated with the help of a sterile pasteur's pippette into cryovial containers. Samples were later stored frozen at $-20^{\circ} \mathrm{C}$ pending analysis.

Random Urine samples (5 mls) were collected in sterile universal containers and used for the determination of micro albumin.

\section{Laboratory procedures}

All reagents used were commercially purchased and the manufacturer's SOP's were followed strictly.

A. Measurements of $\mathbf{C d}, \mathbf{P b}$ and Cr: AAS-HITACHI 180-80 Polarised-zeeman model Atomic Absorption Spectrophotometer was used for the measurements of these metals.

B. Determination of renal parameters (Serum Creatinine and Urea): This was done using using COBAS C111 Chemistry auto analyzer.

C. Determination of micro albumin in urine: This was done using Latex particles coated with specific antibodies anti-human albumin.

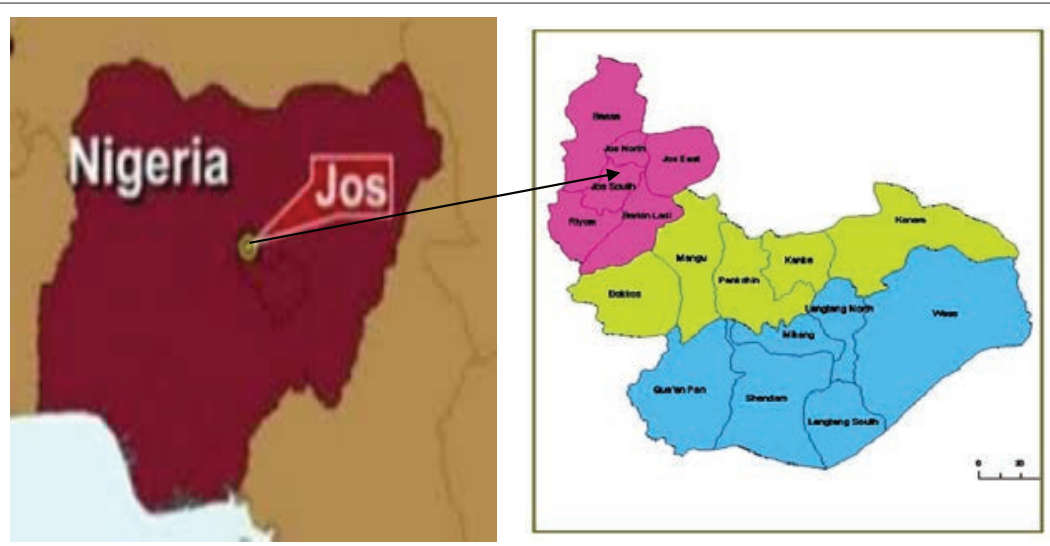

Figure 1: Map of Plateau State showing the study area. 


\section{Statistical analysis}

Data collected from the interview and the laboratory results of blood levels of heavy metals, biochemical parameters (renal indices), and urinary micro albumin were analyzed using Statistical Package for Social Sciences (SPSS) version 23. Both the mean and standard deviations were computed.The comparison between control and study group was analyzed using Student t-test. Chi square was also used to ascertain any relationship between occupation and eGRF. The values were expressed as mean and standard deviation $( \pm \mathrm{SD})$. Results were presented in tables.

\section{Results}

The mean levels of Cadmium, Lead and Chromium are depicted in table 1. Welders had the highest level of Cd $(1.81 \pm 0.08)$ and $\mathrm{Cr}$ $(0.11 \pm 0.02)$ at $\mathrm{p}<0.05$; the highest level of $\mathrm{Pb}$ was seen among car painters $(0.16 \pm 0.03)$ at $\mathrm{p}<0.05$. While $\mathrm{Pb}$ was detected in significantly high levels among battery repairers, petrol hawkers and car painters. Elevated Cd levels were among welders and car painters only. Cr was only detected among welders.

Table 2 shows comparison of mean values of biochemical parameters in various occupations. Data showed higher and significant mean values $(\mathrm{P}<0.005)$ of urea creatinine and micro albumin among battery repairers, Petrol hawkers, car painters and welders.

The mean and standard deviation data of the comparison between the groups mean values of biochemical parameters in the various occupations is as shown in table 3 . The mean values of Creatinine and Micro Albumin were statistically $(\mathrm{p}<0.05)$ significant.

Table 4 shows the existing relationship between occupation and mean eGFR among test and control groups. Car painters who had eGFR $<90 \mathrm{ml} / \mathrm{min}$ i.e., $77(96.3 \%)$ had the lowest clearance rate followed by battery Repairers and Iron Welders, 60(75.0\%) and 57(71.3\%), respectively. Tin Miners had the highest clearance rate of $80(100.0 \%)$.

The data on serum Creatinine, eGFR and Urea mean levels in the tests (exposed) and control groups are shown in table 5. In an attempt to look at the probable long term effects of heavy metals on the kidneys exposure in relation to the non-exposed. Mean eGFR, mean serum creatinine and urea levels of the groups were compared. Mean serum creatinine levels and mean eGFR of the exposed individuals were statistically $(\mathrm{p}<0.05)$ significant when compared to the control individuals.

Table 5 shows a relationship between eGFR for Tests (exposed) and control groups.

Table 1: Levels of heavy metals (ppm) in the study population.

\begin{tabular}{|l|c|c|c|c|c|c|}
\hline \multicolumn{1}{|c|}{ Parameters Study group } & $\begin{array}{c}\text { Cd Control Mean } \\
\pm \text { SD }\end{array}$ & $\begin{array}{c}\text { Total } \\
\text { Mean } \pm \text { SD }\end{array}$ & $\begin{array}{c}\text { Pb Control } \\
\text { Mean } \pm \text { SD }\end{array}$ & $\begin{array}{c}\text { Total } \\
\text { Mean } \pm \text { SD }\end{array}$ & $\begin{array}{c}\text { Cr Control Mean } \\
\pm \text { SD }\end{array}$ & $\begin{array}{c}\text { Total } \\
\text { Mean } \pm \text { SD }\end{array}$ \\
\hline Welders $(\mathbf{n}=\mathbf{8 0})$ & $0.21 \pm 0.02$ & $\begin{array}{c}1.81 \pm 0.08 \\
P=0.000^{*}\end{array}$ & $0.07 \pm 0.00$ & $\begin{array}{c}0.06 \pm 0.00 \\
P=0.068\end{array}$ & $0.07 \pm 0.00$ & $\begin{array}{c}0.11 \pm 0.02 \\
P=0.000^{*}\end{array}$ \\
\hline Battery repairers $(\mathbf{n}=\mathbf{8 0})$ & $0.21 \pm 0.02$ & $\begin{array}{c}0.24 \pm 0.03 \\
P=0.389\end{array}$ & $0.07 \pm 0.00$ & $\begin{array}{c}0.08 \pm 0.01 \\
P=0.036^{*}\end{array}$ & $0.07 \pm 0.00$ & $\begin{array}{c}0.06 \pm 0.00 \\
P=0.059\end{array}$ \\
\hline $\begin{array}{l}\text { Petrol hawkers } \\
(\mathbf{n}=\mathbf{8 0})\end{array}$ & $0.21 \pm 0.02$ & $\begin{array}{c}0.23 \pm 0.03 \\
P=0.519\end{array}$ & $0.07 \pm 0.02$ & $\begin{array}{c}0.16 \pm 0.03 \\
P=0.000^{*}\end{array}$ & $0.07 \pm 0.00$ & $0.06 \pm 0.00$ \\
\hline $\begin{array}{l}\text { Car painters } \\
(\mathbf{n}=\mathbf{8 0})\end{array}$ & $0.21 \pm 0.02$ & $\begin{array}{c}0.04 \pm 0.00 \\
P=0.000^{*}\end{array}$ & $0.07 \pm 0.00$ & $\begin{array}{c}0.80 \pm 0.04 \\
P=0.000^{*}\end{array}$ & $0.07 \pm 0.00$ & $\begin{array}{c}0.06 \pm 0.00 \\
P=0.068\end{array}$ \\
\hline $\begin{array}{l}\text { Tin Miners } \\
(\mathbf{n}=\mathbf{8 0})\end{array}$ & $0.21 \pm 0.02$ & $\begin{array}{c}0.20 \pm 0.02 \\
P=0.575\end{array}$ & $0.07 \pm 0.00$ & $\begin{array}{c}0.06 \pm 0.00 \\
P=0.081\end{array}$ & $0.07 \pm 0.00$ & $\begin{array}{c}0.06 \pm 0.00 \\
P=0.055\end{array}$ \\
\hline
\end{tabular}

$\mathrm{p}<0.05$ is significant $*$ implies significant.

Table 2: Comparison of mean values of biochemical parameters in various occupations.

\begin{tabular}{|c|c|c|c|c|c|c|}
\hline $\begin{array}{l}\text { Biochemical } \\
\text { Parameters }\end{array}$ & $\begin{array}{c}\text { Control }(n=200) \\
\text { Mean } \pm \text { SD }\end{array}$ & $\begin{array}{c}\text { Welders }(n=80) \\
\text { Mean } \pm \text { SD }\end{array}$ & $\begin{array}{c}\text { Battery Repairers }(n=80) \\
\text { Mean } \pm \text { SD }\end{array}$ & $\begin{array}{c}\text { Petrol hawkers }(n=80) \\
\text { Mean } \pm \text { SD }\end{array}$ & $\begin{array}{c}\text { Car painters }(n=80) \\
\text { Mean } \pm S D\end{array}$ & $\begin{array}{c}\text { Tin miners }(n=80) \\
\text { Mean } \pm \text { SD }\end{array}$ \\
\hline Urea (mmol/l) & $7.64 \pm 0.40$ & $\begin{array}{c}10.43 \pm 3.40 \\
p=0.004^{*}\end{array}$ & $\begin{array}{l}4.79 \pm 1.89 \\
p=0.000^{*}\end{array}$ & $\begin{array}{c}4.81 \pm 1.06 \\
p=0.000^{*}\end{array}$ & $\begin{array}{c}11.20 \pm 3.15 \\
p=0.000^{*}\end{array}$ & $\begin{array}{c}4.13 \pm 0.51 \\
p=0.000^{*}\end{array}$ \\
\hline Creatinine ( $\mu \mathrm{mol})$ & $81.80 \pm 8.54$ & $\begin{array}{c}113.66 \pm 35.05 \\
p=0.000^{*}\end{array}$ & $\begin{array}{c}4.79 \pm 1.89 \\
p=0.000^{*}\end{array}$ & $\begin{array}{c}75.01 \pm 7.66 \\
p=0.000^{*}\end{array}$ & $\begin{array}{c}119.10 \pm 16.33 \\
p=0.000^{*}\end{array}$ & $\begin{array}{c}70.36 \pm 5.62 \\
p=0.000^{*}\end{array}$ \\
\hline $\begin{array}{l}\text { Microalbumin } \\
\text { (mg/l) }\end{array}$ & $5.09 \pm 4.97$ & $\begin{array}{c}13.01 \pm 5.16 \\
p=0.000^{*}\end{array}$ & $\begin{array}{c}12.58 \pm 5.24 \\
p=0.000^{*}\end{array}$ & $\begin{array}{c}5.18 \pm 3.26 \\
p=0.955\end{array}$ & $\begin{array}{c}13.10 \pm 5.00 \\
p=0.000^{*}\end{array}$ & $\begin{array}{c}5.15 \pm 4.45 \\
p=0.933\end{array}$ \\
\hline
\end{tabular}

$\mathrm{P}<0.05$ is significant * implies significant

Table 3: Comparison of mean values of biochemical parameters in the various occupations.

\begin{tabular}{|l|c|c|c|}
\hline \multicolumn{1}{|c|}{ Biochemical Parameters } & $\begin{array}{c}\text { Non-exposed (n=400) } \\
\text { Mean } \pm \text { SD }\end{array}$ & $\begin{array}{c}\text { Exposed }(\mathbf{n = 2 0 0 )} \\
\text { Mean } \pm \text { SD }\end{array}$ & T \\
\hline Urea (mmol/l) & $7.64 \pm 0.40$ & $8.03 \pm 3.74$ & -1.488 \\
\hline Creatinine $(\mu \mathrm{mol})$ & $81.80 \pm 8.54$ & $97.25 \pm 28.48$ & -7.502 \\
\hline Microalbumin $(\mathrm{mg} / \mathrm{l})$ & $5.10 \pm 4.97$ & $11.99 \pm 9.01$ & -10.078 \\
\hline
\end{tabular}

$\mathrm{P}<0.05$ is significant * implies significant 
Table 4: Relationship between occupation and eGFR.

\begin{tabular}{|c|c|c|c|c|c|}
\hline Occupation & eGFR $<90 \mathrm{ml} / \mathrm{min} \mathrm{N}(\%)$ & eGFR $\geq 90 \mathrm{ml} / \mathrm{min} \mathrm{N}(\%)$ & Mean eGFR & $\chi^{2}$ & $\mathbf{P}$ \\
\hline Iron Welder $(n=80)$ & $57(71.3)$ & $23(28.7)$ & 77.24 & 244.146 & $0.000 *$ \\
\hline Battery Repairer ( $n=80$ ) & $60(75.0)$ & $20(25.0)$ & 73.70 & & \\
\hline Petrol hawkers $(n=80)$ & $5(6.3)$ & $75(93.8)$ & 110.83 & & \\
\hline Car painters $(n=80)$ & $77(96.3)$ & $3(3.8)$ & 67.96 & & \\
\hline Tin Miner $(n=80)$ & $0(0.0)$ & $80(100.0)$ & 119.51 & & \\
\hline Control & $41(17.1)$ & $159(44.2)$ & 99.31 & & \\
\hline
\end{tabular}

$\mathrm{P}<0.05$ is significant * implies significant

Table 5: Relationship between eGFR for exposed and non exposed group

\begin{tabular}{|l|c|c|c|}
\hline \multicolumn{1}{|c|}{ Biochemical Parameters } & $\begin{array}{c}\text { Creatinine } \\
\text { Mean } \pm \text { SD }\end{array}$ & $\begin{array}{c}\text { UGFR } \\
\text { Mean } \pm \text { SD }\end{array}$ & $99.31 \pm 12.93$ \\
\hline Non Exposed $(\mathbf{n = 2 0 0 )}$ & $81.80 \pm 8.54$ & $89.85 \pm 28.69$ & $7.64 \pm 0.40$ \\
\hline Exposed $(\mathbf{n}=\mathbf{4 0})$ & $97.25 \pm 28.48$ & $0.000 *$ & $8.03 \pm 3.74$ \\
\hline $\mathbf{P}$ & $0.000 *$ & $8.03 \pm 3.74$ & \\
\hline
\end{tabular}

$\mathrm{P}<0.05$ is significant * implies siginificant

The mean eGFR $60 \mathrm{~mL} / \mathrm{min}$ in the exposed group was statistically $(\mathrm{p}<0.05)$ significant $(82.9 \%)$ when compared to the control $(17.1 \%)$. Likewise those with a mean eGFR $\geq 90 \mathrm{~mL} / \mathrm{min}$ were also higher in the exposed and statistically $(\mathrm{p}<0.05)$ significant $(55.8 \%)$ as compared to control (44.2\%) (Table 6).

The Mean Levels of Urinary Micro Albumin $(\mathrm{Mg} / \mathrm{L})$ Exposed Workers and Non-Exposed by Age Group are shown in table 7. It revealed significant mean levels $(\mathrm{P}<0.05)$ of micro albumin $(\mathrm{mg} / \mathrm{L})$ amongst welders $(13.01 \pm 5.16)$, battery repairers $(12.58 \pm 5.24)$, petrol hawkers $(16.11 \pm 15.63)$ and car painters $(13.10 \pm 5.00)$ when compared to the control group $(5.10 \pm 4.97)$. However, there was no statistical significance recorded among tin miners $(5.15 \pm 4.45)(\mathrm{P}>0.05)$.

Table 8 shows mean levels of urinary micro albumin $(\mathrm{mg} / \mathrm{L})$ among the exposed group compared to non-exposed by age. The highest levels of urinary micro albumin (14.66 \pm 9.70$)$ which was statistically significant $(\mathrm{P}<0.05)$, was measured among the age bracket of $36-40$ while the least values were seen in those between the ages of 26-30 $(7.81 \pm 6.33)$. In this study, none of the subjects in the non-exposed group (control) was below 25 years of age and none were above 50 years of age.

\section{Discussion}

The heavy metal data analysis in table 1 clearly shows that $\mathrm{Cd}$ and $\mathrm{Cr}$ are found particularly in welders whereas $\mathrm{Pb}$ is implicated among battery repairers, petrol hawkers and car painters in Jos. The bioaccumulation of these metals in their blood samples in relation to the control group revealed a statistically increased levels $(\mathrm{p}<0.05)$ which were far above the recommended reference ranges [12]. These results indicate that continued exposure to chemicals and substances in a work-related environment is capable of impacting negatively on the overall health status of workers.

Findings from our studies also suggest a high possibility of occurrence of renal impairment among exposed individuals. Tables $2,3,5,7,8$ showed statistically significant increased in serum levels of creatinine and micro albumin $(\mathrm{p}<0.05)$, respectively; among the exposed group when compared to the controls (exposed).

These findings may not be unconnected to the impairment of protein metabolism by heavy metals, particularly Lead and Cadmium and since Urea is the end product of protein catabolism, it was affected.
Creatinine is a key index in measuring kidney function and is nitrogenous constituent of the blood. It is more readily excreted by the kidneys than Urea. The elevation of the serum creatinine concentrations observed in this study is highly significant in suggesting that the exposed individuals would have lost a considerable percentage of their kidney function [13].

Sufficient evidence abound that chronic low levels of some heavy elements may affect kidney function [14,15]. From our study, Table 5 shows that serum creatinine, urea and eGRF mean values of the exposed were increased and was statistically significant $(\mathrm{p}<0.05)$ compared to the controls. These findings, though in contrast to the work of Wang VS, et al., and Goyer RA $[16,17]$ who reported that workers with excessive Lead exposure for over ten years did not exhibit any renal dysfunction; Our findings is in concordance to that of Pinto de Almeida AR, et al. [18] Who found that exposed smelter workers had high serum creatinine level and renal dysfunction.

The percentage eGFR $<69$ of car painters, iron welders and battery repairers was $96.3 \%, 71.3 \%$ and $75.0 \%$, respectively and was statistically significant $(\mathrm{p}<0.005)$ as against that of the other artisans (Petrol hawkers and Tin Miners) supporting the fact that kidney damage with loss of kidney function exist severely among Car painters, followed by Iron welders and Battery repairers. This is well supported by urinary micro albumin presence in the urine of the exposed person, which also increased and attained statistical significance $(\mathrm{p}<0.05)$ as well, (Table 8). As established, when the renal capacity to produce MT is overwhelmed, renal tubular dysfunction may occur, and this can be seen by the increased urinary excretion of low molecular weight (LMW) proteins such as beta-2-microglobulin (B2-MG) [19-21].

In comparing the kidney function of the test versus the control groups, lead and cadmium are known poisons to the kidney causing injury to the proximal tubules of the nephron. $82.9 \%$ of the test groups had impaired GFR as compared to $17.1 \%$ of the control. Such a difference was statistically significant $(\mathrm{p}<0.05)$. This is in contrast to the findings of Njoroge GK, et al. [22] when they examined the effects of lead exposure among battery repairers in Adis Ababa. Similarly in contrast to the work of Karimooy HN, et al. [23] in Iran whose work showed no correlation between Lead exposure and kidney dysfunction while studying workers at the traditional tiles factory, on effect of occupational Lead exposure on kidney function. 
Table 6: Serum Creatinine (SC), eGFR and Urea levels of test and control groups.

\begin{tabular}{|l|c|c|c|c|}
\hline \multicolumn{1}{|c|}{ Group } & eGFR<60 & eGFR $\geq \mathbf{9 0}$ & $\boldsymbol{X}^{\mathbf{2}}$ & $\mathbf{P}$ \\
\hline Control ( $\mathbf{n = 2 0 0 )}$ & $41(17.1)$ & $159(44.2)$ & 47.531 & $0.000^{*}$ \\
\hline Test $(\mathbf{n}=\mathbf{4 0 0 )}$ & $199(82.9)$ & $201(55.8)$ & & \\
\hline Total & 240(100.0) & $360(100.0)$ & & \\
\hline
\end{tabular}

$\mathrm{P}<0.05$ is significant * implies significant

Table 7: Mean levels of urinary micro albumin $(\mathrm{Mg} / \mathrm{L})$ of exposed workers by enterprise.

\begin{tabular}{|l|c|c|c|c|}
\hline \multicolumn{1}{|c|}{ Enterprise } & $\begin{array}{c}\text { No of } \\
\text { Workers }\end{array}$ & $\begin{array}{c}\text { Micro albumin } \\
\text { (mg/L) } \\
\text { Mean } \pm \text { SD }\end{array}$ & T & p-value \\
\hline Control & 200 & $5.10 \pm 4.97$ & - & - \\
\hline Welders & 80 & $13.01 \pm 5.16$ & -11.919 & ${ }^{*} 0.000$ \\
\hline Battery Repairers & 80 & $12.58 \pm 5.24$ & -11.207 & ${ }^{*} 0.000$ \\
\hline Petrol hawkers & 80 & $16.11 \pm 15.63$ & -6.183 & ${ }^{*} 0.000$ \\
\hline Car painters & 80 & $13.10 \pm 5.00$ & -12.162 & ${ }^{*} 0.000$ \\
\hline Tin Miners & 80 & $13.10 \pm 5.00$ & -0.088 & ${ }^{*} 0.000$ \\
\hline
\end{tabular}

*There is a significant difference between exposed and non exposed group by using independent $t$-test at $p<0.05$.

Table 8: Mean levels of urinary micro albumin $(\mathrm{Mg} / \mathrm{L})$ exposed workers and non-exposed by age group.

\begin{tabular}{|c|c|c|c|c|}
\hline Age group & $\begin{array}{c}\text { Non exposed } \\
(\mathbf{n = 4 0 0 )} \\
\text { Mean } \mathbf{\text { SD }}\end{array}$ & $\begin{array}{c}\text { Exposed }(\mathbf{n = 2 0 0 )} \\
\text { Mean } \pm \text { SD }\end{array}$ & $\mathbf{T}$ & p-value \\
\hline $\mathbf{1 5 - 2 0}$ & - & $6.02 \pm 5.69$ & - & \\
\hline $\mathbf{2 1 - 2 5}$ & - & $15.42 \pm 12.30$ & - & \\
\hline $\mathbf{2 6 - 3 0}$ & $6.46 \pm 4.50$ & $7.81 \pm 6.33$ & -0.865 & 0.390 \\
\hline $\mathbf{3 1 - 3 5}$ & $1.03 \pm 0.88$ & $10.98 \pm 6.49$ & -12.411 & ${ }^{*} 0.000$ \\
\hline $\mathbf{3 6 - 4 0}$ & $4.54 \pm 3.60$ & $14.66 \pm 9.70$ & -8.478 & ${ }^{*} 0.000$ \\
\hline $\mathbf{4 1 - 4 5}$ & $11.78 \pm 1.39$ & $13.38 \pm 6.44$ & -1.064 & 0.293 \\
\hline $\mathbf{4 6 - 5 0}$ & $12.13 \pm 3.65$ & $9.42 \pm 5.14$ & 2.033 & $* 0.048$ \\
\hline $\mathbf{5 1 - 5 5}$ & - & $13.63 \pm 3.62$ & - & - \\
\hline $\mathbf{5 6 - 6 0}$ & - & $13.66 \pm 12.08$ & - & - \\
\hline Total & $5.10 \pm 4.97$ & $11.99 \pm 9.01$ & -10.078 & 0.000 \\
\hline
\end{tabular}

*There is a significant difference between exposed and non exposed group by using independent t-test at $p<0.05$.

From our study, the car painters are the most affected workers, having the highest value of both Urea and Creatinine $(11.2 \pm 3.15$ and $119.10 \pm 16.33$ ) respectively, with $96.3 \%$ of them having impaired kidney function followed by battery repairers (75.0\%) and iron welders (71.3\%).

\section{Conclusions}

Our study suggests that prolong exposure to heavy metals $(\mathrm{Cd}, \mathrm{Pb}$ and $\mathrm{Cr}$ ) has the tendency to impact negatively on the renal parameters of artisans who are particularly engaged in welding, battery repairers, petrol hawkers and car painting. This study therefore suggests a periodic check of biochemical parameters in these workers in order to prevent the onset of Chronic Kidney Disease (CKD) due to heavy metal bioaccumulation.

\section{References}

1. Pollack AZ, Mumford SL, Mendola P, Perkins NJ, Rotman $Y$, et al. (2015) Kidney biomarkers associated with blood lead, mercury, and cadmium in premenopausal women: a prospective cohort study. J Toxicol Environ Health A 78: 119-131.

2. Coresh J, Byrd-Holt D, Astor BC, Briggs JP, Eggers PW, et al. (2007) Chronic kidney disease awareness, prevalence, and trends among U.S. adults, 1999 to 2000. J Am Soc Nephrol 16: 180-188.

3. Batuman V, Landy E, Maesaka JK, Wedeen RP (1983) Contribution of lead to hypertension with renal impairment. N Engl J Med 309: 17-21.

4. Jin T, Wu X, Tang Y, Nordberg M, Bernard A (2004) Environmental epidemiological study and estimation of benchmark dose for renal dysfunction in a cadmium-polluted area in China. Biometals 17: 525530.

5. Jos Metropolitan Development Board (2009) Jos greater master plan. 11-15.

6. Winder C, Stacey NH (2004) Toxicity of Metals. In: Winder C, Stacey $\mathrm{NH}$ (eds) Occupational Toxicology $2^{\text {nd }}$ edition, CRC Press, United States 294-335.

7. Tranter M (2004) Occupational hygiene and risk management. $2^{\text {nd }}$ edition, Allen and Unwin, Crows Nest, Australia 99-119.

8. Aw TC, Gardiner KS, Harrington JM (2007) Pocket Consultant Occupational Health. $5^{\text {th }}$ edition, Blackwell Publishing, United States.

9. Herber RF, Duffus JH, Christensen JM, Otsen E, Park MV (2001) Risk assessment for occupational exposure to chemicals. A review of current methodology (IUPAC Technical Report). Pure Appl Chem 73: 993-1031.

10. Saunders M, Lewis P, Thornhil A (2009) Research Methods for Business Students. $5^{\text {th }}$ Edition, Prentice Hall, United States 581-582.

11. Famodu AA, Osilesi O, Makinde YO, Osonuga OA (1998) Blood pressure and blood lipid levels among vegetarian, semi-vegetarian, and non-vegetarian native Africans. Clin Biochem 31: 545-549.

12. Singh R, Gautam N, Mishra A, Gupta R (2011) Heavy metals and living system: An overview. Indian J Pharmacol 43: 246-253.

13. Kaplan A, Szabo LL (1983) Clinical chemistry: interpretation and techniques. Second Edition, Lea and Febiger 481.

14. Bernard BP, Becker CE (1988) Environmental lead exposure and the kidney. J Toxicol Clin Toxicol 26: 1-34.

15. Lim YC, Chia KS, Ong HY, Ng V, Chew YL (2001) Renal dysfunction in workers exposed to inorganic lead. Ann Acad Med Singapore 30: 112-117.

16. Wang VS, Lee MT, Chiou JY, Guu CF, Wu CC, et al. (2002) Relationship between blood lead levels and renal function in lead battery workers. Int Arch Occup Environ Health 75: 569-575.

17. Goyer RA (1989) Mechanisms of lead and cadmium nephrotoxicity. Toxicol Lett 46: 153-162.

18. Pinto de Almeida AR, Carvalho FM, Spinola AG, Rocha H (1987) Renal dysfunction in Brazilian lead workers. Am J Nephrol 7: 455-458.

19. Chaumont A, De Winter F, Dumont X, Haufroid V, Bernard A (2011) The threshold level of urinary cadmium associated with increased urinary excretion of retinol-binding protein and beta 2-microglobulin: a re-assessment in a large cohort of nickelcadmium battery workers. Occup Environ Med 68: 257-264. 
20. Järup L (2003) Hazards of heavy metal contamination. Br Med Bull 68: 167-182.

21. Kido T, Kobayashi E, Hayano M, Nogawa K, Tsuritani I, et al. (1995) Significance of elevated urinary human intestinal alkaline phosphatase in Japanese people exposed to environmental cadmium. Toxicol Lett 80: 49-54.

22. Njoroge GK, Njagi EN, Orinda GO, Sekadde-Kigondu CB, Kayima JK (2008) Environmental and occupational exposure to lead. East Afr Med J 85: 284-291.

23. Karimooy HN, Mood MB, Hosseini M, Shadmanfar S (2010) Effects of occupational lead exposure on renal and nervous system of workers of traditional tiles factories in Mashhad (northeast of Iran). Toxicol Ind Health 26: 633-638. 